\title{
Effects of commonly used pesticides (demond, granland and safacol) on non-targeted organisms (wheat plant, soil nematodes, microfungi and aerobic mesophilic bacteria) in Muş Province, Turkey
}

\author{
İbrahim Koç a,* (D), Emrullah Urgan a iD, Ayșenur Güven a iD, Birgül Ilıkhan b iD \\ a Bitlis Eren University, Department of Environmental Engineering, TR-13000, Bitlis Turkey \\ b Bitlis Eren University, Department of Biology, TR-13000, Bitlis Turkey
}

\section{A R T I C LE IN F O}

\section{Article history:}

Received 26 April 2020

Received in revised form 26 April 2020

Accepted 01 May 2020

\section{Keywords:}

Root and above-ground components,

Aerobic mesophilic bacteria,

Microfungi,

Nematode,

Pesticide

\begin{abstract}
A B S TRACT
Chemical drugs (pesticides) that are xenobiotic to the nature of agricultural agro-ecosystems affect the target organism and non-target factors. The efficiency and reliability of agricultural areas are important not only for living creatures in the environment, but also for community. This study was carried out to determine the effects of Demond EC 2.5 (insecticide), Granland DF (herbicide) and Safacol 70 WP (fungicide) pesticides, which are widely used in the agricultural areas of Muş, on the development of nontarget wheat plant, free-living nematodes, microfungi and aerobic mesophilic bacteria communities. The study was performed in three replicates in the variance analysis method for repeated measurements in laboratory conditions. Pesticides were applied by spraying to the pots including one $\mathrm{kg}$ of soil as recommended and upper doses, respectively, with the help of an injector. Repeated Measurement ANOVA and Profile Analysis Technique were used in the comparison of treatments in terms of nematode, bacteria and microfungi numbers (before-after), and the Analysis of Means (ANOM) Technique in comparing treatments in terms of plant parameters. As a result of the experiments; While the effect of only periods is important for the bacteria combination $(\mathrm{P}=0.001)$; for the microfungi community, both period $(\mathrm{P}=0.004)$ and Period $\times$ Treatment interaction were found significant $(\mathrm{P}=0.050)$. Periodic $\times$ Treatment interaction was statistically significant for plant-parasitic, omnivore-predator, bacterivore and total nematodes respectively $(\mathrm{P}=0.002 ; \mathrm{P}=0.004 ; \mathrm{P}=0.001 ; \mathrm{P}=0.000)$. As a result; the pesticides used had more or less positive effects on the microfungi community, while they had a negative effect on the bacteria community; According to trophic levels, soil nematodes and plant parameters were found to have a positive / negative effect. It is thought that pesticides should be used in the last resort and recommended dosage, without forgetting that the soil is complex and all living things share this environment.
\end{abstract}

(C) 2020. Turkish Journal Park Academic. All rights reserved.

\section{Introduction}

Agro-ecosystems are complex environments and the activities carried out here affect productivity, as well as sustainability, environmental and human health. Manufacturers prefer using chemical pesticides to get more crops from agricultural areas. In this context, Özbek and Fidan (2014), although the differences from time to time, between 1979 to 2007 pesticide use increased by $270 \%$ in Turkey. Quinn et al. (2011) reported that although the benefit provided by pesticides cannot be denied, the negativities it gives to the environment and human

\footnotetext{
* Corresponding author.

Tel.: +0 505477 1198; fax: +0 0000000000

E-mail address: ibrahimkoc47@gmail.com

ORCID : 0000-0003-0803-6801 (İbrahim KOÇ), 0000-0003-0131-3052 (Emrullah URGAN), 0000-0002-0976-7545 (Ayşenur GÜVEN), 0000-0003-4629-1192 (Birgül ILIKHAN)
} 
health cannot be ignored. The indiscriminate use of pesticides affects soil microflora, fauna and flora (Arora et al., 2019). ALAni et al. (2019) reported that pesticides, in which they applied different doses, negatively affect the microbial activities of bacteria, microfungi and actinomycetes in the soil, and significantly reduced their number. Ekundayo (2003) found that among the pesticides treated to the garden soil at the recommended doses, Agrosan is the most negative pesticide affecting bacteria density. Ubuoh et al. (2012) observed that glyphosphate treatments caused a significant reduction in microfungi and bacteria population compared to control. Ören et al. (2009) stated that the pesticides they use show different effects on bacteria and yeast-molds in the soil. Demirci et al. (2002) have listed the fungicides they use against fungi to be effective (Flusilazole, Tebuconazole, Diniconazole, Penconazole, Cyproconazole, Triticonazole). Arora and Sahni (2016) reported that microorganisms react differently to different pesticides. Heinonen-Tanski et al. (1989) reported that soil microorganisms were affected by pesticides used in their studies in some cases, but not in all cases. Lo (2010) stated that pesticides have different effects against soil microorganisms due to their different structure. Küçük et al. (2009) concluded that some fungicides may negatively affect the development of fungal isolates (T. harzianum, a biocontrol factor). Koç and Yardım (2019) reported that the pesticides (herbicides and fungicides) they used did not significantly affect soil microfungi and aerobic mesophilic bacteria density. Güven and Koç (2020a) found that the bacteria population in the pesticide treated samples compared to the control treatment showed a decrease in other treatments, while the microfungi population increased only in the treatment of Pesos 100 EC. Wesley et al. (2017), they observed that different results were obtained according to the parameters considered.

Arora and Sahni (2016) predicted that chemical pesticides disrupt the activities of soil microorganisms and therefore the nutritional quality of the soil may be affected, and this situation may lead to serious ecological consequences. Küçük et al. (2016) reported that it is inevitable to use fungicides in the fight against pest and therefore it should be used considering the effect of the fungicides to be used on soil microorganisms. Johns (2017) stated that soil microbiology should be better understood in order for agricultural production to meet the needs of the growing world population. Yardim and Edwards (1998) stated that nematodes (according to trophic groups) respond positively / negatively to pesticides used in field trials. Daramola et al. (2015) reported that Carbofuran's nematode population was significantly suppressed. Römbke et al. (2009) stated that the pesticides they used reduced the number of nematodes by $48 \%$ compared to the control. Koç et al. (2020), according to their compliance analysis, found significant relationships between pesticide treatments and nematode groups. Güven and Koç (2020b) declared that the pesticides they use affect soil nematodes. Demircioğlu (2007) stated that herbicides tested in different environments and shapes affect the number of seed germination, sugar beet wet, dry and root weight. Fındıklı and Türkoğlu (2010) found that all doses of pesticides they use have an inhibitory effect on cell division at the root ends of Allium cepa. Siddiquı and Ahmed (2006) observed that the pesticide concentrations they use have combined effects on plant growth and the nutritional composition of seeds. Niewiadomska and Klama (2005) have demonstrated that the pesticides they apply have a toxic effect on the nodulation and root growth of the tested plants. Boutin et al. (2014) stated that as a result of the use of pesticides, a large number of non-targeted plants and vegetation have changed significantly, in addition, there is a delay in flowering and a decrease in seed production. Ilıkhan and Koç (2020) reported that Demond EC 2.5 and Safacol 70 WP had a toxic effect on E. fetida. This study was conducted for the purpose of determining the effects of Demond EC 2.5 (insecticide), Granland DF (herbicide) and Safacol 70 WP (fungicide), which are widely used in agricultural areas of the province of Muș, Turkey on the free-living nematodes, microfungi and aerobic mesophilic bacteria communities.

\section{Material and Methods}

This study was carried out in in-vitro conditions (mean temperature: $23{ }^{\circ} \mathrm{C}$ ) between 2019-2020. The soil used in the study is from the pasture environment (Latitude: $38^{\circ}$ 28'54.75", Longitude: $42^{\circ} 9^{\prime} 51.93^{\prime \prime}$ ) and 0-30 cm depth (Yıldız et al., 2019) for the agricultural activities in the Bitlis Eren University Campus area. Taken on August 2, 2019. Samples were passed through a $2 \mathrm{~mm}$ sieve and kept in clean nylon bags at $+4{ }^{\circ} \mathrm{C}$ in the refrigerator until experimenting. Soil texture, according to Bouyoucos (1951) (clay ratio; 32\%, silt ratio; $5 \%$, sand ratio; 63\%, lime ratio; $1.43 \%, \mathrm{pH} ; 7.8, \mathrm{EC} ; 181 \mu \mathrm{S} / \mathrm{cm}^{-1}$ ); Moisture content (\%) was determined before and after treatment $(12.7 \%, 14.6 \%)$ according to Craze (1990). For 2017, pesticides commonly used in the province of Muş were determined by asking the Muş Provincial Directorate of Agriculture and Forestry, pesticides and farmers. A total of three [Demond EC 2.5 (insecticide, Deltamethrin $25 \mathrm{~g} / \mathrm{l}$ active substance), Granland DF (herbicide, 75\% Tribenuron-methyl) and Safacol 70 WP (fungicide, 70\% Propineb)] were used to represent the pesticide groups. Trial measurements were carried out in three replications according to the variance analysis method (Figure 1). Before the pesticide treatment, Ceyhan-99 bread wheat seeds (twenty piece) were planted 3 $\mathrm{cm}$ deep. Determined pesticides were used with the help of injector (5 cc) as twice the recommended dose and the recommended dose. Demond EC $2.5(200 \mathrm{ml}$ distilled water + $0.1 \mathrm{ml}$ drug; $200 \mathrm{ml}$ distilled water $+0.2 \mathrm{ml}$ drug), Granland DF (150 ml distilled water $+0.02 \mathrm{mg}$ drug; $150 \mathrm{ml}$ distilled water + $0.04 \mathrm{mg}$ drug), and Safacol $70 \mathrm{WP}$ (200 ml of distilled water $+0.5 \mathrm{~g}$ of drug; $200 \mathrm{ml}$ of distilled water $+1 \mathrm{~g}$ of drug) was prepared by spraying $50 \mathrm{ml}$ of solution (distilled water + drug) into pots placed in a $\mathrm{kg}$ of soil. 


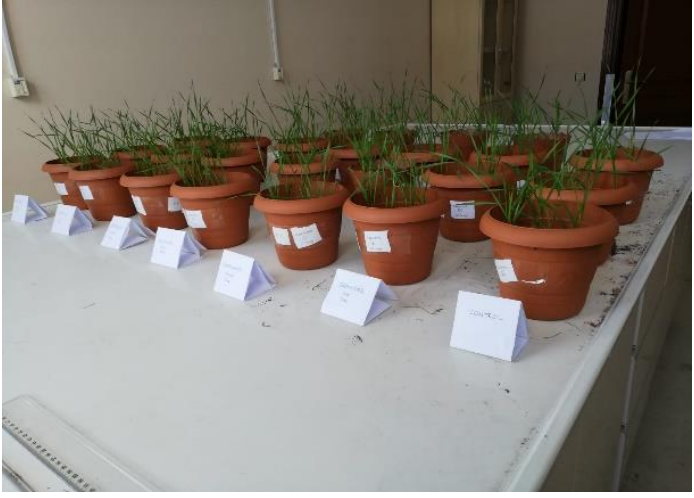

Figure 1. Sample image from trial.

The average sprouting time of the seeds was 4 days. After sprouting, 10 plants were left in each pot. The experiment lasted about a month (January 7 - February 3, 2019) and soil samples were taken before and after pesticide treatment, according to nematode counts (trophic groups), microfungi, and aerobic mesophilic bacteria were examined. The determination of the total number of microfungi and aerobic mesophilic bacteria was done according to Benson (2001). Plate Count Agar for bacteria count and Rose Bengalchloramphenicol Agar media were used for microfungi count. For extraction and counting of nematodes, "ImprovedBaermann Funnel Method" according to was used (Baermann, 1917; Whitehead and Hemming, 1965; Southey, 1986), the microscope's lens $(\times 10)$ counts according to Yeates $(1971)$ and Yeates et al. (1993). The dismantling process was removed from the soil by carefully washing it thoroughly with water after the soil in the pots was removed together with the plants. For each pot, five randomly selected plants were taken to represent the whole of the cleaned plants, and measurements were made. Wheat plants root length $(\mathrm{cm})$, seedling length $(\mathrm{cm})$, root weight $(\mathrm{g})$, seedling weight $(\mathrm{g})$, dry root weight $(\mathrm{g})$, dry seedling weight (g), dry root/seedling ratio and root volume $\left(\mathrm{cm}^{3}\right)$ measurements (Geçit et al., 1987; Sönmez, 2001; Sipan, 2014). In the investigation of the effects of pesticide treatments (before and after treatment), Repeated Measured Variance Analysis and Profile Analysis Techniques were used to compare the treatments in terms of plant parameters (ANOM) Technique (Mendeș et al., 2007; Mendeș, 2012). SPSS (ver. 19.0) and Minitab (ver. 17) statistical package programs were used in making statistical analyzes.

\section{Results and Discussion}

\subsection{Effect of pesticide treatments on soil-free nematodes}

\subsubsection{Effect of treatments on plant-parasitic nematode count}

According to the repeatedly measured variance analysis on the data obtained, the Period $\times$ Treatment interaction effect was found statistically significant $(\mathrm{P}=0.002)$. In other words, the effect of pesticide treatments on the number of plant-parasitic nematodes varied significantly in periods (Table 1).
Table 1. Introductory statistics in terms of plant-parasitic nematode number.

\begin{tabular}{lccc}
\hline \multicolumn{1}{c}{$\begin{array}{c}\text { Pesticide } \\
\text { Treatments }\end{array}$} & $\mathrm{N}$ & $\begin{array}{c}\text { Before } \\
\text { Treatment }\end{array}$ & $\begin{array}{c}\text { After } \\
\text { Treatment }\end{array}$ \\
\cline { 2 - 4 } & $\overline{\boldsymbol{X}} \pm \boldsymbol{S}_{\overline{\boldsymbol{x}}}$ & $\overline{\boldsymbol{X}} \pm \boldsymbol{S}_{\overline{\mathbf{x}}}$ \\
\hline $\begin{array}{l}\text { Demond recommended } \\
\text { d. }\end{array}$ & 3 & $2.00 \pm 0.47$ & $7.33 \pm 0.90$ \\
$\begin{array}{l}\text { Demond a single high d. } \\
\text { Granland }\end{array}$ & 3 & $9.67 \pm 0.67$ & $3.33 \pm 0.60$ \\
$\begin{array}{l}\text { recommended d. } \\
\text { Granland a single high }\end{array}$ & 3 & $8.00 \pm 0.94$ & $4.33 \pm 0.69$ \\
$\begin{array}{l}\text { d. } \\
\text { Safacol recommended }\end{array}$ & 3 & $16.00 \pm 1.33$ & $3.67 \pm 0.64$ \\
d. & & & \\
$\begin{array}{l}\text { Safacol a single high d. } \\
\text { Control }\end{array}$ & 3 & $4.00 \pm 0.94$ & $11.00 \pm 1.10$ \\
Total & 3 & $15.00 \pm 1.29$ & $4.67 \pm 0.79$ \\
& 21 & $9.05 \pm 1.00$ & $5.67 \pm 0.79$ \\
\hline
\end{tabular}

When the results of the profile analysis are examined, the granland did not affect any toxic effect, except for the relative negative in the recommended dose. Even, it has been determined that demond has a positive effect on the increase in the number of plant-parasitic nematodes in recommended doses and safacol treatments (Table 1, Figure 2).

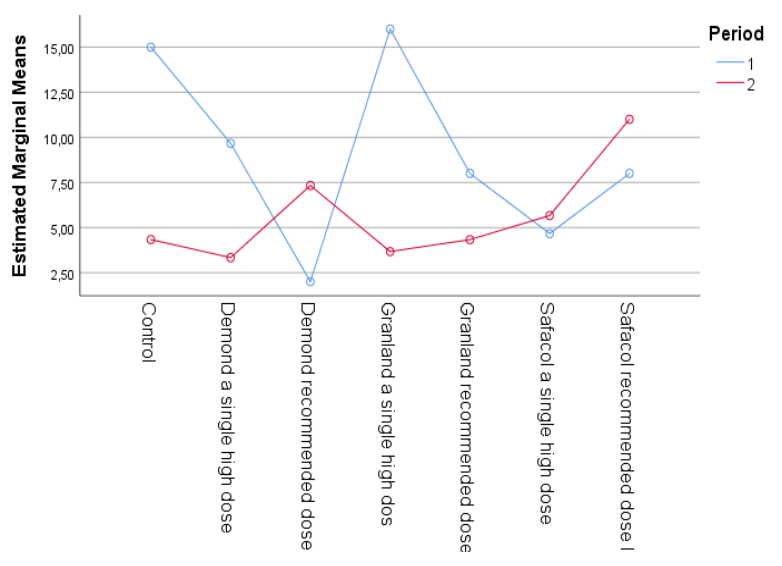

Figure 2. Profile analysis in terms of plant-parasitic nematode number.

* Period 1: Before treatment, Period 2: After treatment

\subsubsection{Effects of treatments on fungivore nematode count}

As a result of repeated measured variance analysis on the obtained data, the Period $\times$ Treatment interaction effect was not statistically significant $(\mathrm{P}=0.265)$. Therefore, the effect of pesticide treatments on fungivore nematode numbers did not change significantly according to periods (Table 2).

Table 2. Effects of treatments on fungivore nematode count.

\begin{tabular}{lccc}
\hline \multicolumn{1}{c}{$\begin{array}{c}\text { Pesticide } \\
\text { Treatments }\end{array}$} & N & $\begin{array}{c}\text { Before } \\
\text { Treatment }\end{array}$ & $\begin{array}{c}\text { After } \\
\text { Treatment }\end{array}$ \\
\cline { 3 - 4 } & & $\overline{\boldsymbol{X}} \pm \boldsymbol{S}_{\overline{\boldsymbol{x}}}$ & $\overline{\boldsymbol{X}} \pm \boldsymbol{S}_{\overline{\boldsymbol{x}}}$ \\
\hline Demond recommended d. & 3 & $3.00 \pm 0.57$ & $2.33 \pm 0.51$ \\
Demond a single high d. & 3 & $2.67 \pm 0.54$ & $2.00 \pm 0.47$ \\
Granland recommended d. & 3 & $5.00 \pm 0.74$ & $2.33 \pm 0.51$ \\
Granland a single high d. & 3 & $5.67 \pm 0.79$ & $4.00 \pm 0.67$ \\
\hline
\end{tabular}




\begin{tabular}{lccc}
\hline Safacol recommended d. & 3 & $2.67 \pm 0.54$ & $2.00 \pm 0.47$ \\
Safacol a single high d. & 3 & $5.33 \pm 0.77$ & $2.33 \pm 0.51$ \\
Control & 3 & $2.67 \pm 0.54$ & $8.00 \pm 0.94$ \\
Total & 21 & $3.86 \pm 0.65$ & $3.29 \pm 0.60$ \\
\hline
\end{tabular}

When the results of the profile analysis on the data are examined; according to the control, all pesticide treatments seem to have a negative effect on fungivore nematodes (Table 2, Figure 3).

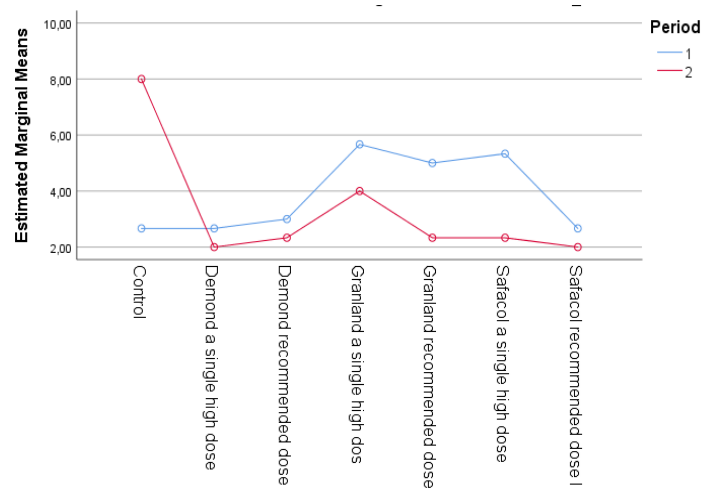

Figure 3. Profile analysis in terms of the number of fungivore nematodes.

* Period 1: Before treatment, Period 2: After treatment

\subsubsection{The effect of treatments on the number of bacterivore nematodes}

As a result of repeated measured variance analysis, the Period $\times$ Treatment interaction effect was found statistically significant $(\mathrm{P}=0.001)$. Therefore, the effect of pesticide treatments on the number of bacterivore nematodes varied significantly over periods (Table 3 ).

Table 3. Introductory statistics in terms of bacterivore nematode number.

\begin{tabular}{lccc}
\hline \multicolumn{1}{c}{$\begin{array}{c}\text { Pesticide } \\
\text { Treatments }\end{array}$} & N & $\begin{array}{c}\text { Before } \\
\text { Treatment }\end{array}$ & $\begin{array}{c}\text { After } \\
\text { Treatment }\end{array}$ \\
\cline { 2 - 4 } & & $\overline{\boldsymbol{X}} \pm \boldsymbol{S}_{\overline{\boldsymbol{x}}}$ & $\overline{\boldsymbol{X}} \pm \boldsymbol{S}_{\overline{\boldsymbol{x}}}$ \\
\hline Demond recommended d. & 3 & $13.33 \pm 1.22$ & $16.33 \pm 1.35$ \\
Demond a single high d. & 3 & $9.33 \pm 1.02$ & $18.00 \pm 1.41$ \\
Granland recommended d. & 3 & $20.67 \pm 1.51$ & $9.00 \pm 1.00$ \\
Granland a single high d. & 3 & $19.33 \pm 1.46$ & $10.33 \pm 1.07$ \\
Safacol recommended d. & 3 & $10.67 \pm 1.09$ & $19.67 \pm 1.48$ \\
Safacol a single high d. & 3 & $8.00 \pm 0.94$ & $27.67 \pm 1.75$ \\
Control & 3 & $27.33 \pm 1.74$ & $41.00 \pm 2.13$ \\
Total & 21 & $15.52 \pm 1.31$ & $20.29 \pm 1.50$ \\
\hline
\end{tabular}

Looking at the results of profile analysis; according to the control, it was observed that especially granland had a negative effect on bacterivore nematodes (Table 3, Figure 4).

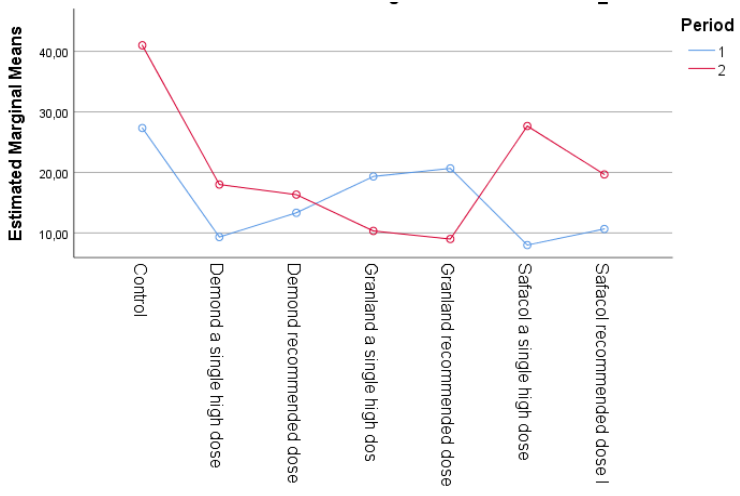

Figure 4. Profile analysis in terms of bacterivore nematode count.

* Period 1: Before treatment, Period 2: After treatment

\subsubsection{The effects of treatments on the number of omnivore-predator nematodes}

As a result of repeated measured variance analysis, the Period $x$ Treatment interaction effect was found statistically significant $(\mathrm{P}=0.004)$. In other words, the effect of pesticide treatments on the number of omnivore-predator nematodes varied significantly in periods (Table 4).

Table 4. Introductory statistics in terms of the number of omnivorepredator nematodes.

\begin{tabular}{lccc}
\hline \multicolumn{1}{c}{$\begin{array}{c}\text { Pesticide } \\
\text { Treatments }\end{array}$} & $\mathrm{N}$ & $\begin{array}{c}\text { Before } \\
\text { Treatment }\end{array}$ & $\begin{array}{c}\text { After } \\
\text { Treatment }\end{array}$ \\
\cline { 2 - 4 } & & $\overline{\boldsymbol{X}} \pm \boldsymbol{S}_{\overline{\boldsymbol{x}}}$ & $\overline{\boldsymbol{X}} \pm \boldsymbol{S}_{\overline{\boldsymbol{x}}}$ \\
\hline Demond recommended d. & 3 & $3.67 \pm 0.64$ & $9.33 \pm 1.02$ \\
Demond a single high d. & 3 & $3.67 \pm 0.64$ & $9.67 \pm 1.04$ \\
Granland recommended d. & 3 & $10.67 \pm 1.09$ & $8.67 \pm 0.98$ \\
Granland a single high d. & 3 & $6.67 \pm 0.86$ & $8.00 \pm 0.94$ \\
Safacol recommended d. & 3 & $4.67 \pm 0.72$ & $11.00 \pm 1.10$ \\
Safacol a single high d. & 3 & $4.67 \pm 0.72$ & $19.33 \pm 1.46$ \\
Control & 3 & $13.33 \pm 1.22$ & $27.33 \pm 1.74$ \\
Total & 21 & $6.76 \pm 0.87$ & $13.33 \pm 1.22$ \\
\hline
\end{tabular}

Looking at the results of profile analysis; according to the control, it was found that demond and granland had negative effects on omnivore-predator nematodes (Table 4, Figure 5).

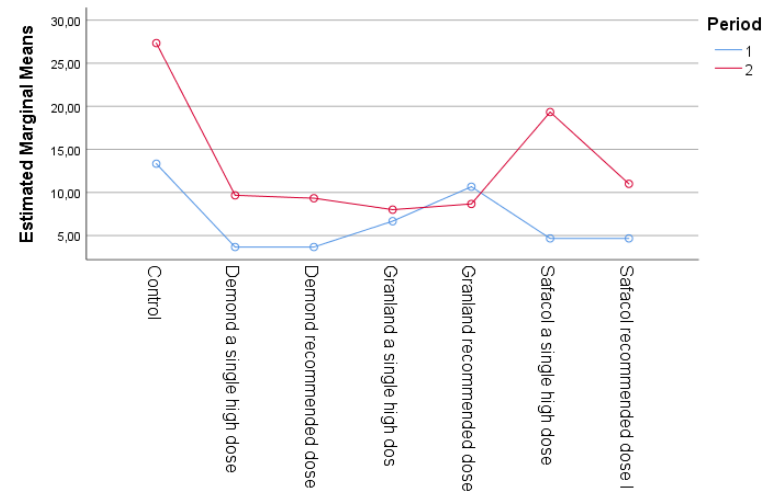

Figure 5. Profile analysis in terms of number of omnivorepredator nematodes.

* Period 1: Before treatment, Period 2: After treatment 


\subsubsection{The effects of treatments on the total number of nematodes}

As a result of repeated measured variance analysis, the Period $\times$ Treatment interaction effect was found statistically significant $(\mathrm{P}=0.000)$. Therefore, the effect of pesticide treatments on the total number of nematodes varied significantly over periods (Table 5).

Table 5. Introductory statistics in terms of total number of nematodes.

\begin{tabular}{lccc}
\hline \multicolumn{1}{c}{$\begin{array}{c}\text { Pesticide } \\
\text { Treatments }\end{array}$} & N & $\begin{array}{c}\text { Before } \\
\text { Treatment }\end{array}$ & $\begin{array}{c}\text { After } \\
\text { Treatment }\end{array}$ \\
\cline { 2 - 4 } & & $\overline{\boldsymbol{X}} \pm \boldsymbol{S}_{\overline{\boldsymbol{x}}}$ & $\overline{\boldsymbol{X}} \pm \boldsymbol{S}_{\overline{\boldsymbol{x}}}$ \\
\hline Demond recommended d. & 3 & $21.67 \pm 1.55$ & $35.33 \pm 1.98$ \\
Demond a single high d. & 3 & $25.33 \pm 1.68$ & $33.00 \pm 1.91$ \\
Granland recommended d. & 3 & $44.00 \pm 2.21$ & $24.33 \pm 1.64$ \\
Granland a single high d. & 3 & $47.33 \pm 2.29$ & $26.00 \pm 1.70$ \\
Safacol recommended d. & 3 & $26.00 \pm 1.70$ & $43.67 \pm 2.20$ \\
Safacol a single high d. & 3 & $22.67 \pm 1.59$ & $55.00 \pm 2.47$ \\
Control & 3 & $58.00 \pm 2.54$ & $80.67 \pm 3.00$ \\
Total & 21 & $35.00 \pm 1.97$ & $42.57 \pm 2.17$ \\
\hline
\end{tabular}

Looking at the results of profile analysis; according to the control, it was observed that especially granland had a negative effect on total nematodes (Table 5, Figure 6).

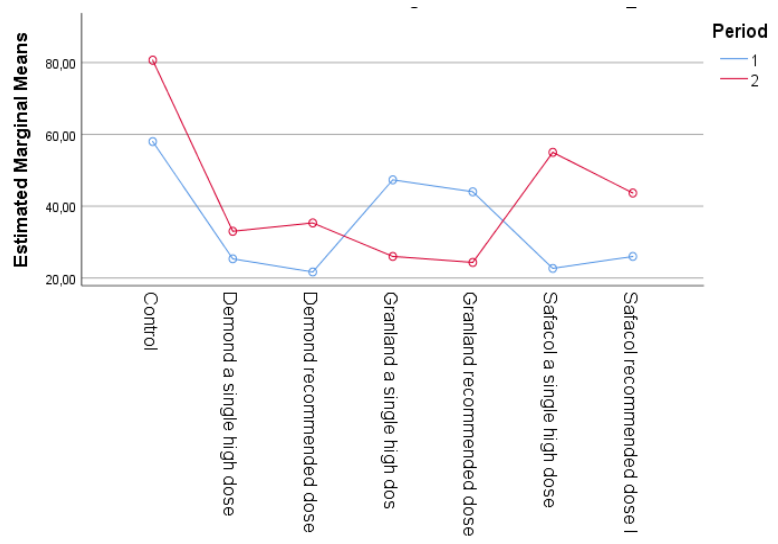

Figure 6. Profile analysis in terms of total number of nematodes. * Period 1: Before treatment, Period 2: After treatment

\subsection{Effect of pesticide treatments on soil microorganisms}

\subsubsection{The effects of treatments on the number of aerobic mesophilic bacteria}

As a result of repeated measured variance analysis, the Period $\times$ Treatment interaction effect was not found statistically significant $(\mathrm{P}=0.835)$. Therefore, the effect of pesticide treatments on aerobic mesophilic bacteria number did not change significantly according to periods (Table 6).
Table 6. Introductory statistics in terms of the number of aerobic mesophilic bacteria.

\begin{tabular}{|c|c|c|c|}
\hline \multirow{2}{*}{$\begin{array}{c}\text { Pesticide } \\
\text { Treatments }\end{array}$} & \multirow[t]{2}{*}{$\mathrm{N}$} & Before Treatment & After Treatment \\
\hline & & $\overline{\bar{X}} \pm S_{\bar{x}}$ & $\overline{\bar{X}} \pm S_{\bar{x}}$ \\
\hline $\begin{array}{l}\text { Demond } \\
\text { recommend } \\
\text { ed d. }\end{array}$ & 3 & $1766666.67 \pm 443.05$ & $22333333.33 \pm 1575.27$ \\
\hline $\begin{array}{l}\text { Demond a } \\
\text { single high } \\
\text { d. }\end{array}$ & 3 & $\begin{array}{c}15666666.67 \pm 1319 \\
37\end{array}$ & $25000000.00 \pm 1666.67$ \\
\hline $\begin{array}{l}\text { Granland } \\
\text { recommend } \\
\text { ed d. }\end{array}$ & 3 & $\begin{array}{c}18000000.00 \pm 1414 \\
21\end{array}$ & $32333333.33 \pm 1895.41$ \\
\hline $\begin{array}{l}\text { Granland a } \\
\text { single high } \\
\text { d. }\end{array}$ & 3 & $8000000.00 \pm 942.81$ & $26000000.00 \pm 1699.67$ \\
\hline $\begin{array}{l}\text { Safacol } \\
\text { recommend } \\
\text { ed d. }\end{array}$ & 3 & $3333333.33 \pm 608.58$ & $14666666.67 \pm 1276.57$ \\
\hline $\begin{array}{l}\text { Safacol a } \\
\text { single high } \\
\text { d. }\end{array}$ & 3 & $3200000.00 \pm 596.28$ & $30333333.33 \pm 1835.86$ \\
\hline Control & 3 & $766666.67 \pm 291.86$ & $33666666.67 \pm 1934.10$ \\
\hline Total & 21 & $7247619.05 \pm 897.38$ & $26333333.33 \pm 1710.53$ \\
\hline
\end{tabular}

When the profile analysis results are examined, it has been found that pesticide treatments have more or less negative effects on the number of aerobic mesophilic bacteria compared to the control (Table 6, Figure 7).

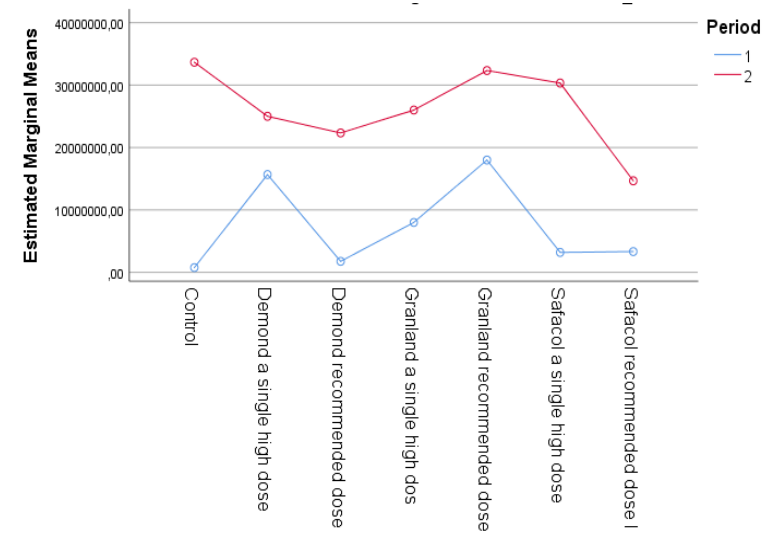

Figure 7. Profile analysis in terms of the number of aerobic mesophilic bacteria.

* Period 1: Before treatment, Period 2: After treatment

\subsubsection{The effect of treatments on the number of microfungi}

As a result of repeated measured variance analysis, the Period $x$ Treatment interaction effect was found statistically significant $(\mathrm{P}=0.050)$. Therefore, the effect of pesticide treatments on the number of microfungi varied significantly in periods (Table 7). 
Table 7. Introductory statistics in terms of microfungi number.

\begin{tabular}{lccc}
\hline \multicolumn{1}{c}{$\begin{array}{c}\text { Pesticide } \\
\text { Treatments }\end{array}$} & $\mathrm{N}$ & $\begin{array}{c}\text { Before } \\
\text { Treatment }\end{array}$ & After Treatment \\
\cline { 2 - 4 } & $\overline{\boldsymbol{X}} \pm \boldsymbol{S}_{\overline{\boldsymbol{x}}}$ & $\overline{\boldsymbol{X}} \pm \boldsymbol{S}_{\overline{\boldsymbol{x}}}$ \\
\hline $\begin{array}{l}\text { Demond } \\
\text { recommended d. }\end{array}$ & 3 & $2333.33 \pm 16.10$ & $4700.00 \pm 22.85$ \\
$\begin{array}{l}\text { Demond a single } \\
\text { high d. }\end{array}$ & 3 & $2400.00 \pm 16.33$ & $3666.67 \pm 20.18$ \\
$\begin{array}{l}\text { Granland } \\
\text { recommended d. }\end{array}$ & 3 & $2333.33 \pm 16.10$ & $3600.00 \pm 20.00$ \\
$\begin{array}{l}\text { Granland a single } \\
\text { high d. }\end{array}$ & 3 & $3533.33 \pm 19.81$ & $4366.67 \pm 22.03$ \\
$\begin{array}{l}\text { Safacol } \\
\text { recommended d. }\end{array}$ & 3 & $1733.33 \pm 13.88$ & $3700.00 \pm 20.27$ \\
$\begin{array}{l}\text { Safacol a single } \\
\text { high d. }\end{array}$ & 3 & $3600.00 \pm 20.00$ & $3766.67 \pm 20.46$ \\
$\begin{array}{l}\text { Control } \\
\text { Total }\end{array}$ & 3 & $4833.33 \pm 23.17$ & $3533.33 \pm 19.81$ \\
\hline & 21 & $2966.67 \pm 18.15$ & $3904.76 \pm 20.83$ \\
\hline
\end{tabular}

When the profile analysis results were examined, it was found that pesticide treatments had more or less positive effects on the number of microfungi according to the control (Table 7 , Figure 8).

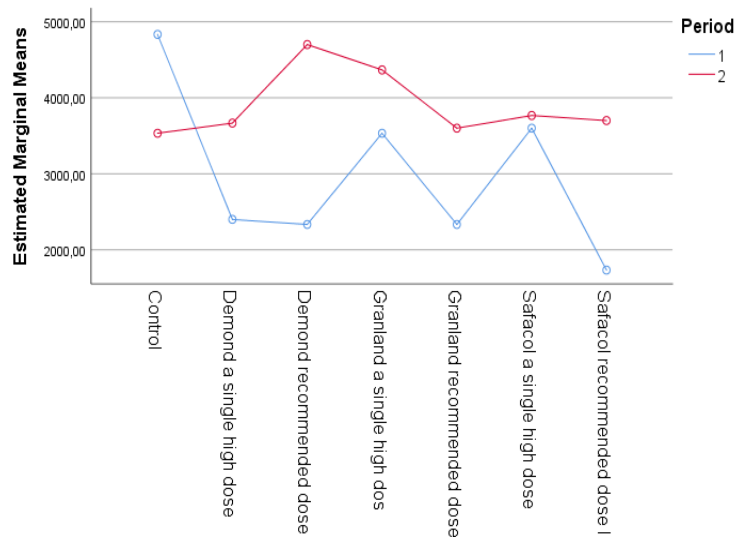

Figure 8. Profile analysis in terms of microfungi number.

* Period 1: Before treatment, Period 2: After treatment

3.3. The effect of pesticide treatments on the development of root and above-ground parts in the first development period of wheat

\subsubsection{Effect of treatments on plant root length (cm)}

According to the ANOM test performed in terms of the effect of pesticide treatments on plant root length, it was observed that safacol had a positive effect and granland had a negative effect compared to the control (Figure 9).

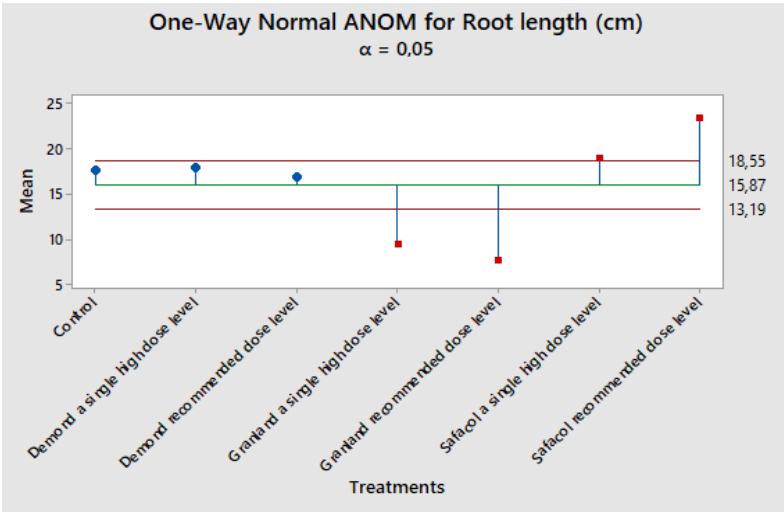

Figure 9. ANOM graphic in terms of plant root length.

\subsubsection{Effect of treatments on plant shoot length (cm)}

According to the ANOM test conducted in terms of the effect of pesticide treatments on plant shoot length, it was found that demond had a positive effect and granland had a negative effect when compared with the control (Figure 10).

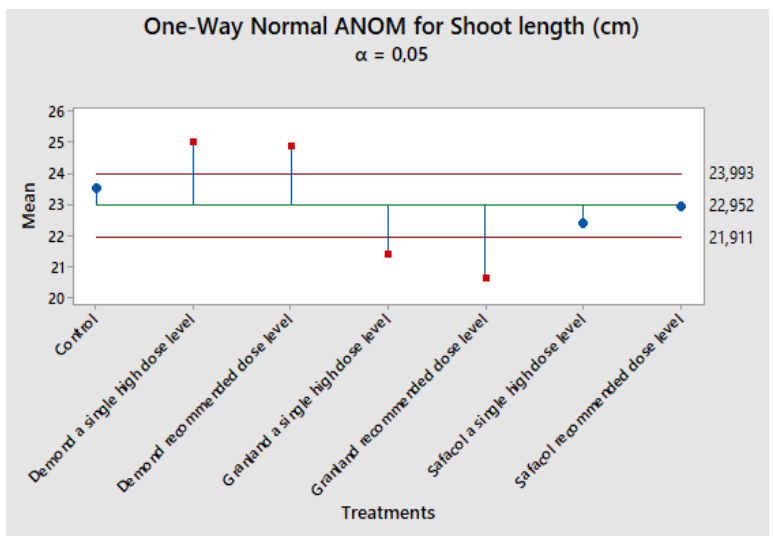

Figure 10. ANOM graphic in terms of plant shoot length.

\subsubsection{Effect of treatments on plant root weight (g)}

According to the ANOM test results in terms of the effect of pesticide treatments on plant root weight, it was found that other treatments that granland had a positive effect compared to the control had a relatively positive effect (Figure 11). 


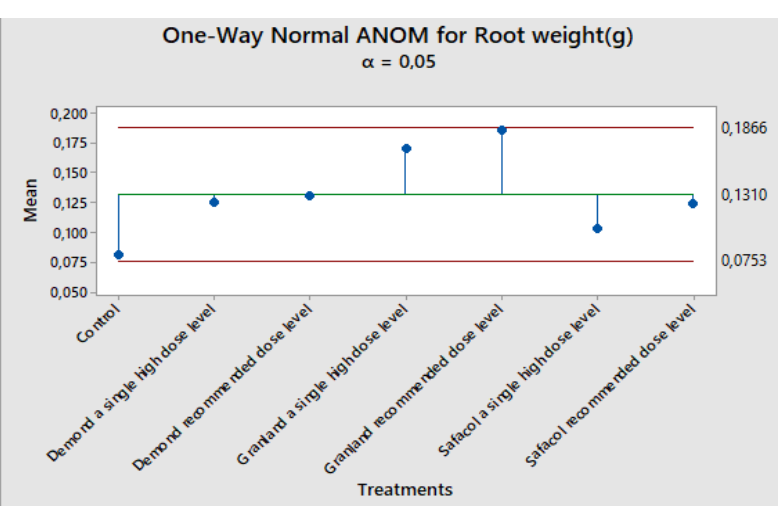

Figure 11. ANOM graphic in terms of plant root weight.

\subsubsection{Effect of treatments on plant shoot weight (g)}

According to the ANOM test performed in terms of the effect of pesticide treatments on plant shoot weight, safacol was found to be positive while other treatments had a positive effect compared to the control (Figure 12).

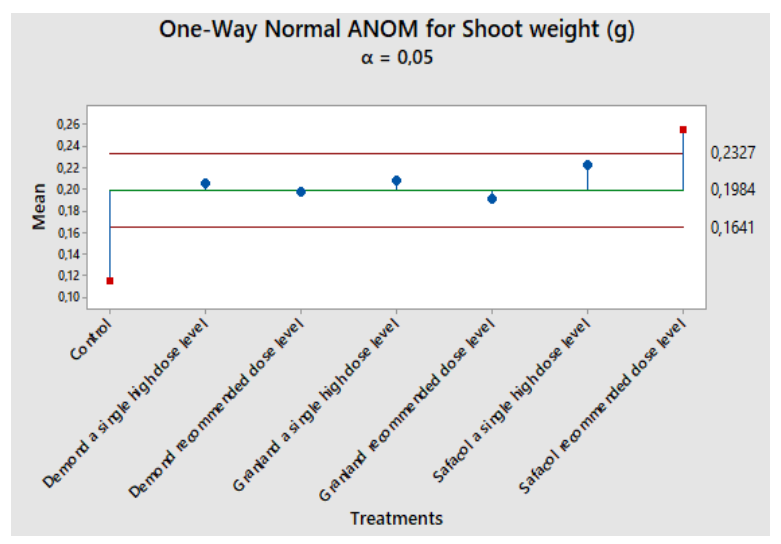

Figure 12. ANOM graphic in terms of plant shoot weight.

\subsubsection{Effect of treatments on plant dry root weight (g)}

According to the ANOM test performed in terms of the effect of pesticide treatments on plant dry root weight, it was found to be relatively affected compared to the control (Figure 13).

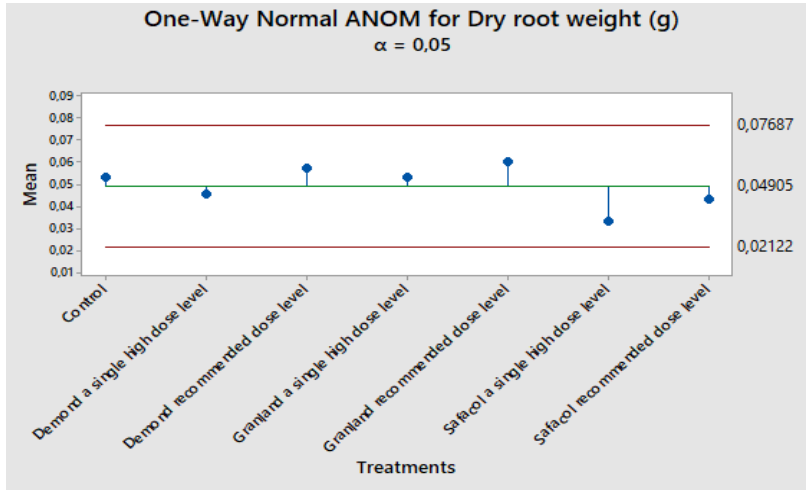

Figure 13. ANOM graphic in terms of plant dry root weight.

\subsubsection{Effect of treatments on plant dry shoot weight (g)}

According to the ANOM test performed in terms of the effect of pesticide treatments on plant dry shoot weight, compared to the control, safacol suggested overdose treatment positively and other treatments affected relatively (Figure 14).

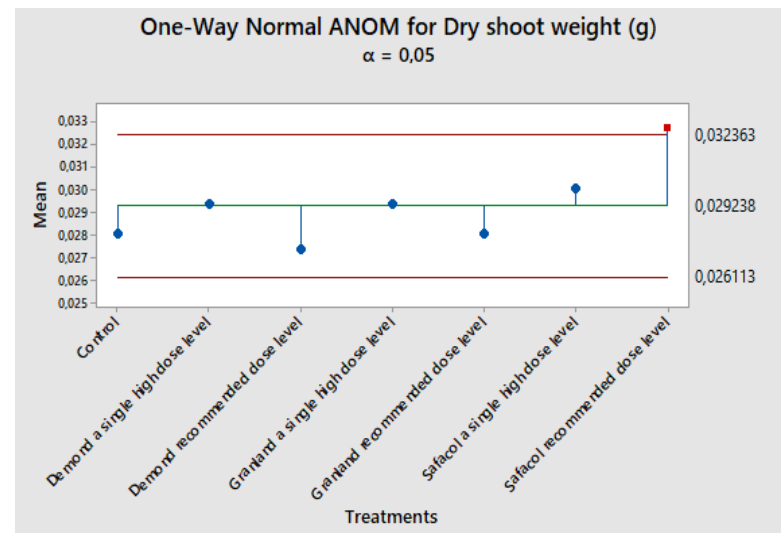

Figure 14.ANOM graphic in terms of plant dry shoot weight.

\subsubsection{Effect of treatments on plant dry root / shoot ratio}

According to the ANOM test performed in terms of the effect of pesticide treatments on the plant dry root / shoot ratio, it was observed that all treatments were relatively affected when compared with the control (Figure 15). 


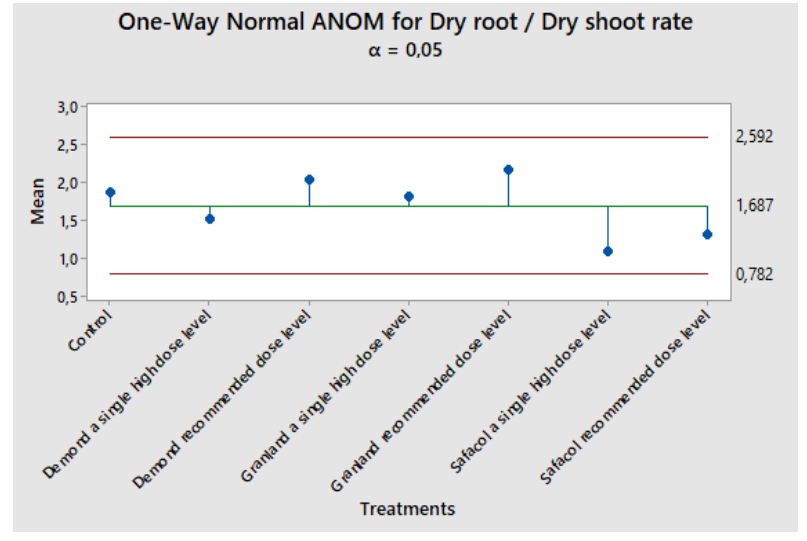

Figure 15. ANOM graphic in terms of plant dry root / shoot ratio.

\subsubsection{Effect of treatments on plant root size $\left(\mathrm{cm}^{3}\right)$}

According to the ANOM test results in terms of the effect of pesticide treatments on plant root size, all pesticide treatments were found to be partially effective compared to the control (Figure 16).

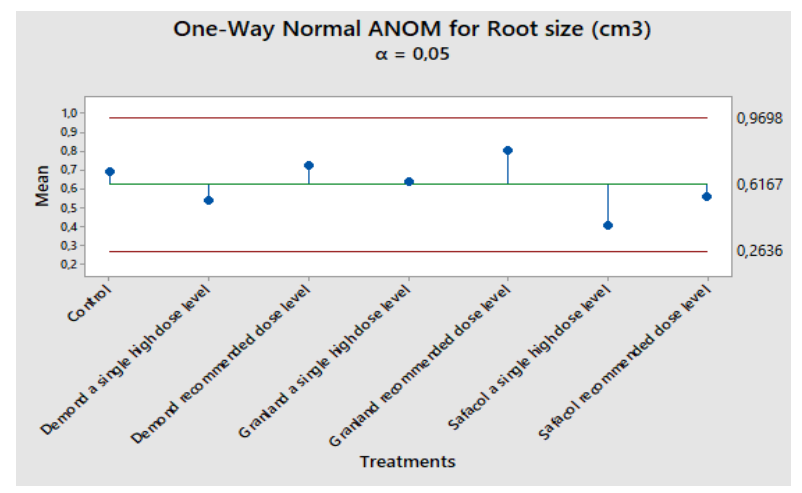

Figure 16. ANOM graphic in terms of plant root size $\left(\mathrm{cm}^{3}\right)$.

Chemical drugs (pesticides) used in disease, pest and weed control not only affect the target parameter, but unfortunately also affect the biotic and abiotic parameters that are not targeted and whose assets are indisputably indispensable. Treatments performed in this study showed positive, negative and neutral effects compared to the control and dosage used in terms of plant growth parameters. The results obtained in this study were partially in agreement with Demircioğlu (2007), Fındıklı and Türkoğlu (2010), Sıddıquı and Ahmed (2006), Niewiadomska and Klama (2005) and Boutin et al. (2014). As free-living nematodes in soil, grandland, which is one of the pesticide treatments, generally shows toxic effects; with the recommended dose of demond, safacol has also been found to have a positive effect on plant-parasitic nematodes and other treatments have different effects. Further, similar outcomes with previous studies including Yardim and Edwards (1998), Römbke et al. (2009) and Koç et al. (2020) were obtained in the laboratory experiments. When evaluated in terms of microfungi; the treatments were found to have more or less positive effects on the number of microfungi. Although some of the findings in this study were contrary to the suggestions proposed by AL-Ani et al. (2019), Ubuoh et al. (2012) and Küçük et al. (2009), they were substantially consistent with Wesley et al. (2017), Arora and Sahni (2016), Arora et al. (2019), Ören et al. (2009), Heinonen-Tanski et al. (1989) and Koç and Yardım (2019). In terms of aerob mesophilic bacteria, pesticides were found to have more or less toxic effects. The findings of this study were relatively parallel with Ubuoh et al. (2012), Güven and Koç (2020a) and AL-Ani et al. (2019, Ören et al. (2009), Ekundayo (2003), Heinonen-Tanski et al. (1989), Yousaf et al. (2013), Lo (2010), Arora and Sahni (2016), Aries and Aid (2019) and Wesley et al. (2017). Based on the findings obtained, different results (such as positive, negative and neutral) were obtained, depending on the type and dose of the drug used and the parameter considered. It is thought that this situation may be caused by the variability of factors such as the type of drug used, dosage, parameter taken into account and the environment studied.

As a result; It can be stated that the negative effects of pesticides to the environment cannot be ignored (Quinn et al., 2011; Arora and Sahni, 2016; Küçük et al., 2016) and soil microbiology should be better understood in order for agricultural production to meet the needs of the growing world population (Johns, 2017).

\section{Acknowledgements}

We would like to thank Prof. Mehmet MENDEŞ, Asst. Prof. Dr. Mehmet YILMAZ, Assoc. Prof. Fatih ÇIĞ and Assoc. Prof. Erdal SAKIN for their help in this study. Some of this study was presented as oral presentation at the Black Sea Summit 3rd International Applied Science Congress (25 - 26 April 2020, Ordu, Turkey).

\section{References}

AL-Ani, M.A., Hmoshi, R.M., Kanaan, I.A., and Thanoon, A.A., 2019. Effect of Pesticides on Soil Microorganisms. In Journal of Physics: Conference Series (Vol. 1294, No. 7, p. 072007). IOP Publishing

Arora, S., and Sahni, D., 2016. Pesticides Effect on Soil Microbial Ecology and Enzyme Activity-An Overview. Journal of Applied and Natural Science, 8(2), 1126-1132.

Arora, S., Arora, S., Sahni, D., Sehgal, M., Srivastava, D.S., and Singh, A., 2019. Pesticides Use and Its Effect on Soil Bacteria and Fungal Populations, Microbial Biomass Carbon and Enzymatic Activity. Curr Sci, 116(4), 643-649.

Baermann, G., 1917. Eine einfache Methode zur Auffindung von Ancylostomum (Nematoden) Larven in Erdproben. Geneeskd Tijdschr Ned Indie, 57, 131-137.

Benson, H.J., 2001. Microbiological Applications: A Laboratory Manual in General Microbiology. Harold J. Benson. USA: The McGraw-Hill Companies, pp. 203.

Boutin, C., Strandberg, B., Carpenter, D., Mathiassen, S.K., and Thomas, P.J., 2014. Herbicide Impact on Non-Target Plant Reproduction: What are the Toxicological and Ecological Implications? Environmental Pollution, 185, 295-306.

Bouyoucos, G.J., 1951. A Calibration of the Hydrometer Method for Making Mechanical Analyses of Soils. Agronomy Journal, 43, 434-438.

Craze, B., 1990. Soil Survey Standard Test Method Soil Moisture Content. Department of Sustainable Natural Resources, 1-5. 
Daramola, F., Afolami, S., Enikuomehin, O., Omonhinmin, C.A., Adebayo, H.A., 2015. Nematicidal Effects of Carbofuran and GC-MS Analysis of Its Residue in Pineapple Fruits. International Journal of Agriculture and Biology, 2, 357-362.

Demirci, A., Katırcıoğlu, Y. Z., Demirci, F., 2002. Investigations on the effects of triazole group fungicides on some important antagonistic fungi and non-pathogen Fusarium oxysporum (Schlecht) in vitro. Plant Protection Bulletin, 42(1-4), 53-65.

Demircioğlu, A., 2007. Determination of the Phytotoxic Effects of Some Herbicides Used on Corn to Sugarbeet (Ph. D. Thesis). Ankara University, Graduate School of Natural and Applied Sciences Department of Plant Protection, p.55, Ankara.

Ekundayo, E.0., 2003. Effect of Common Pesticides Used in The Niger Delta Basin of Southern Nigeria on Soil Microbial Populations. Environmental Monitoring and Assessment, 89(1), 35-41.

Findikli, Z., and Türkoğlu, Ş., 2010. The Effects of Glyphos and DDVP on Mitotic Division and Chromosomes in Allium cepa L. J Sci Cumhuriyet Univ,, 31(2), 49-62.

Geçit, H.H., Emeklier, H.Y., Çiftçi, C.Y., Ünver, S., and Şenay, A., 1987. Ekmeklik Buğdayda İlk Gelişme Devresinde Kök ve Toprak Üstü Organların Durumu. Türkiye Tahıl Sempozyumu, 6-9 Ekim 1987, Uludağ Üniversitesi Ziraat Fakültesi, Bursa.

Güven, A., and Koç, İ., 2020a. The Effects of Satellite 20 WP, Status 330 E, Pesos 100 EcC and Pentran 22 E Pesticides on Some Soil Parameters. 3.Uluslararasi Mardin Artuklu Bilimsel Araștirmalar Kongresi, 143144, 18-19 Ocak 2020, Mardin.

Güven, A., and Koç, İ., 2020b. Investigation of the Effects of Some Pesticides Commonly Used in Bitlis on Soil Nematodes. 3.Uluslararasi Mardin Artuklu Bilimsel Araștirmalar Kongresi, 149-150, 18-19 Ocak 2020, Mardin.

Heinonen-Tanski, H., Simojoki, P., Raininko, K., Nuormala, N., and Silvo, R., 1989. Effect of Annual Use of Pesticides on Soil Microorganisms and Sugar Beet Yields. Agricultural and Food Science, 61(1), 45-53.

Ilıkhan, B., and Koç, İ., 2020. Some Biological Parameters of Eisenia fetida (Savigny, 1826) in Pesticide-Applied Vermicompost. KSU J. Agric Nat, 23(2), 367-378.

Johns, C., 2017. Living soils: The Role of Microorganisms in Soil Health. Fut Direct Intl, 1-7.

Koç, İ., and Yardım, E.N., 2019. Investigation of the Effects of Pesticides and Wood Vinegar on Some Microbial and Physico-chemical Soil Parameters. KSU J. Agric Nat, 22(6), 896-904.

Koç, İ., Yıldız, S.., and Yardım, E.N., 2020. Effect of Some Pesticides and Wood Vinegar on Soil Nematodes in a Wheat Agro-Ecosystem. KSU J. Agric Nat, 23(3), 621-633.

Küçük, Ç., Kıvanç, M., Kınacı, E., and Kınacı, G., 2009. Trichoderma harzianum İzolatlarının Şeker Pancarında Kullanılan Bazı Fungisitlere Duyarlılıklarının in vitro'da Araştırılması. Elektronik Mikrobiyoloji Dergisi TR, 7(2), 8-12.

Küçük, Ç., Yeşilorman, D., and Cevheri, C., 2016. Effect of Some Fungicides on Soil Biological Activities in Laboratory Conditions. Adıyaman Üniversitesi Fen Bilimleri Dergisi, 6(2), 187-201.

Lo, C.C., 2010. Effect of pesticides on soil microbial community. Journal of Environmental Science and Health Part B, 45(5), 348-359.

Mendeş M., Dincer E., and Arslan E., 2007. "Profile Analysis and Growth Curve for Body Mass Index of Broiler Chickens Reared Under Different Feed Restrictions in Early Age", Archiv Fur Tierzucht-Archives of Animal Breeding, 4, 403-411.
Mendeş, M., 2012. Uygulamalı Bilimler için İstatistik ve Araştırma Yöntemleri. Kriter Yayınevi, İstanbul.

Niewiadomska, A., and Klama, J., 2005. Pesticide Side Effect on The Symbiotic Efficiency and Nitrogenase Activity of Rhizobiaceae Bacteria Family. Polish Journal of Microbiology, 54(1), 43-48.

Ören, A., Özbolat, K., and Dığrak, M., 2009. Effect of the Some Pesticides on Soil Microorganisms Which Commonly Used in Kahramanmaraş Region. KSU J. Agric Nat,12(1), 23-28.

Özbek, F.Ş., and Fidan, H., 2014. Pesticides Usage in Wheat Production: Case Study of Konya. KSU J. Agric Nat, 17(3), 13-18.

Quinn, L., de Vos, J., Fernandes-Whaley, M., Roos, C., Bouwman, H., Kylin, H., Pieters, R., and van den Berg, J., 2011. Pesticide Use in South Africa: One of the Largest Importers of Pesticides in Africa. InTech, 1, p. 49-96.

Römbke, J., Schmelz, R.M., and Knabe, S., 2009. Field Studies for the Assessment of Pesticides with Soil Mesofauna, in Particular Enchytraeids, Mites and Nematodes: Design and First Results. Soil Organisms, 81(2), 237-264.

Siddiqui, Z.S., and Ahmed, S., 2006. Combined Effects of Pesticide on Growth and Nutritive Composition of Soybean Plants. Pakistan Journal of Botany, 38(3), 721.

Sipan, S., 2014. Some Properties of Root and Shoot of Some Bread Wheat (Triticum aestivum L. Em. Thell.) Cultivars in the First Development Stage (Master Thesis), Van Yüzüncü Yıl University, Msc, Department of Field Crops, p. 53, Van.

Sönmez, F., 2001. Tir buğdayı hatlarında ilk gelişme devresinde kök ve toprak üstü organların durumu. Türkiye 4. Tarla Bitkileri Kongresi, 297-302, 17-21 Eylül 2001, Tekirdağ.

Southey, J. F., 1986. Extract of Meloidogyne Egg Masses. In: Southey JF (ed) Laboratory Methods for Work with Plants and Soil Nematodes. HMSO, London. 42-44 pp.

Ubuoh, E.A., Akhionbare, S.M.O., and Akhionbare, W.N., 2012. Effects of Pesticide Application on Soil Microbial Spectrum: Case Study-Fecolart Demonstration Farm, Owerri-West, Imo State, Nigeria. International Journal of Multidisciplinary Sciences and Engineering, 3(2), 34-39.

Wesley, B., Ajugwo, G., Adeleye, S., Ibegbulem, C., and Azuike, P., 2017. Effects of Agrochemicals (Insecticides) on Microbial Population in Soil. EC Microbiology, 8, 211-221.

Whitehead, A.G., and Hemming, J.R., 1965. A Comparison of Some Quantitative Methods of Extracting Small Vermiform Nematodes from Soil. Annuals of Applied Biology, 55, 25-38.

Yardim, E.N., and Edwards, C.A., 1998. The Effects of Chemical Pest, Disease and Weed Management Practices on The Trophic Structure of Nematode Populations in Tomato Agroecosystems. Applied Soil Ecology, 7(2), 137-147.

Yeates, G.W., 1971. Feeding Types and Feeding Groups in Plant and Soil Nematodes. Pedobiologia, 8, 173-79.

Yeates, G.W., T Bongers., de Goede R.G.M., Freckman, D.W., and Georgleva, S.S., 1993. Feeding Habits in Soil Nematode Families and Genera - An Outline for Soil Ecologists. Journal of Nematology, 25, 315331.

Yıldız, Ş., Koç, İ., and Yardım, E.N., 2017. Investigation on Nematode Faunal Structures in Pastures of Muş Province. YYU J AGR SCI, 27(2), 197-203.

Yousaf, S., Khan, S., and Aslam, M.T., 2013. Effect of Pesticides on the Soil Microbial Activity. Pakistan Journal of Zoology, 45(4), 1063-1067. 